\title{
CATHOLIC MISSIONARIES IN THE EARLY AND IN THE TERRITORIAL DAYS OF IOWA.
}

BY REV. JOHN F. KEMPKER, DAVENPORT, IOWA.

Since the days of Father Marquette and of Father Hennepin, it is not definitely known that any Catholic priest set foot within the present limits of Iowa until about the year 1828 . From that time until 1832, Rev. Fathers Joseph A. Lutz, Charles F. Van Quickenborne, and Francis Vincent Badin made visits to several seattered settlements in this region, as may be seen from the following meagre accounts.

Rev. Joseph A. Lutz was a zealous young German priest, stationed in St. Louis. From this point he made several missionary journeys along the banks of the Mississippi river, of which, however, no record is found, excepting of a protracted visit in 1831 to the people of Prairie du Chien.

Rev. Francis Vincent Badin was an early priest of Detroit. But he must not be eonfounded with Rev. Stephen Theodor Badin, the first priest ordained in the United States, who was also on duty among the Pottawattamie Indians in Indiana from 1830 to 1836 . Rev. Francis V. Badin was stationed at Prairie du Chien, where he signs the registers, "Francois Vint Badin, priest," commencing May 29, 1827. During that year and the years 1828, 1829 and 1830 , he makes many records of baptisms, marriages and burials at Prairie du Chien, Galena and Fever River."

Rev. Charles Felix Van Quickenborne was a zealous and most exemplary Jesuit priest of the province of St. Louis, and of him it is said that he held divine services in the lead mines of Dubuque about the year 1832 .

These priests did what they could for the Indians, and it is probable that they visited the Indians and traders and trappers on the west bank of the Mississippi river.

* See copy of these in "Record of American Historical Society of Philadelphia, September, 1911, pages 164-197. 


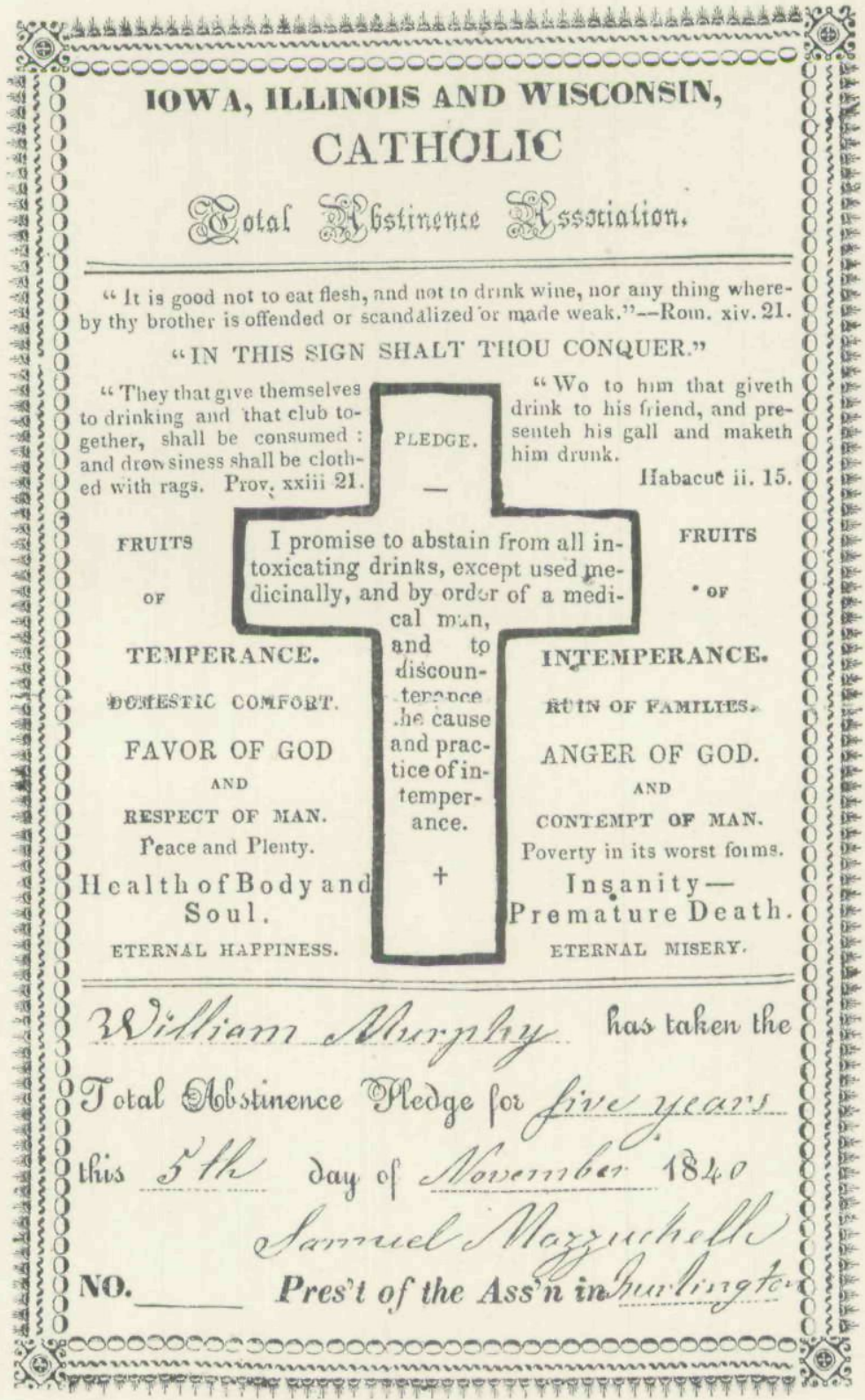

\section{FACSIMILE.}

Temperance Pledge taken by Father Mazzuchelli of a resident of Iowa in 1840. It is the form first introduced in Ireland by Father Mathew in 1838, and soon thereafter into the United States, and in use to the present time by the Catholic Clergy throughout America. 
In the autumn of 1831, Bishop Joseph Rosati, at St. Louis, ordained as priest the Rev. John MeMahon and the following autumn, 1832, appointed him as pastor of Galena, Illinois, with contiguous territory. Father MeMahon arrived at his destination the same autumn and became very active in administering to the spiritual wants of the community, opened a school, had several converts, and in June, 1833, opened a mission station in Dubuque. But on June 19, 1833, he died from an attack of cholera, at Galena, and was buried there.

Bishop Rosati in the early spring of 1834 sent as pastor to Galena the Rev. Charles P. Fitz-Maurice, who divided his time between Galena and Dubuque. He entered claims for church grounds at Dubuque, obtained a subseription for one thousand one hundred dollars, had the boards and timber engaged and contract for the building given out to a carpenter; when in the summer of 1834 he also was snatched away by the cholera and laid to rest with Father MeMahon. Then all the building arrangements were abandoned. During this year Dubuque witnessed the building of a church by the Methodist Episcopals.

When Patrick Quigley built his log house in Dubuque, it became the headquarters of the priests, and was used for divine services until the building of St. Raphael's church.

Samuel Mazzuchelli, for five years a Dominican Friar in Faenza and in Rome, was sent by his superiors to Bishop Fenwick, of Cincinnati, Ohio. He bade Milan farewell and departed from Rome in June, 1828, for Lyons, France, where he studied the French language. On October 5, 1828, he sailed for New York and arrived at Cincinnati the same autumn. Here and at St. Rose Dominican Convent, near Springfield, Kentucky, he continued his studies, especially English, became sacristan of the Cathedral in Cineinnati in 1829 and in September of this year entered the Dominican Convent of St. Joseph's, Perry County, Ohio, to prepare for ordination and there became catechist. In the cathedral in Cincinnati Bishop Fenwick ordained him deacon in July, and priest on September 5,1830 . He was immediately sent as missionary to the Island of Mackinac, where he was received with the greatest joy. 
In the early summer of 1835 , Father Mazzuchelli succeeded to the pastorate of Galena and in the beginning of July made his first visit to Dubuque. He at once made arrangements for building the St. Raphael's church at Dubuque, for which he laid the corner stone on August 15, 1835, and a little later that for St. Michael's church in Galena, bringing both these churches under roof that autumn. He was a very talented and energetic priest, visiting and organizing many congregations, one as early as 1835 , at Davenport, where he commenced the building of a church in 1837 and eompleted it in 1838. It was a two-story brick building, 25 by 40 feet in size and dedicated on May 23, 1839, by Bishop Mathias Loras of Dubuque.

The church at Dubuque was stone, 40 by 80 feet in size.. Of this Eliphalet Price, in Annals of Iowa, October, 1865, page 541 , says :

The first Catholic church erected in Iowa was commenced at Dubuque in the spring of 1835, under the management and direction of an educated and gentlemanly little French priest by the name of Mazzuchelli. This was a stone edifice. We took the contract, and furnished the stone for this building until it was about eight feet high, when we left Dubuque for a more northern latitude. We never transacted business with a more honorable, pleasant and gentlemanly person than the Rev. Mr. Mazzuchelli. We left him seated upon a stone near the building, watching the lazy movements of a lone Irishman, who was working out his subscription in aid of the church. We have never seen him since.

The first priest to extend his visits to the southeastern part of the State was the Rev. P. P. Lefevre, pastor of the St. Paul's church on Salt River, Ralls County, Missouri. He came in 1834, founded two or three small missions in the Black Hawk Purchase (Keokuk in Lee County, 1834, and Moffets Mill, at Augusta on Skunk River, in 1836), and made oceasional visits úntil 1837.

Following him, Rev. August Brickwedde of St. Boniface church, Quincy, Illinois, was given charge of this locality, and he made missionary visits annually for the Easter services to the people of Fort Madison, West Point and "Zucker' Creek, all in Lee County, in the years 1838, 1839 and 1840. He cele- 
brated mass in a log house of John Kempker on Sugar Creek (now St. Paul, Lee County) on May 11, 1838; and during the summer of that year the people of this settlement, the Holtkamps, Hellmanns, Kempkers, Dingmanns, built a $\log$ church on a site four miles northwest from West Point, which constitutes the present St. James church at St. Paul.

Pope Gregory XVI, on July 28, 1837, created the diocese of Dubuque, in Wiseonsin Territory, with jurisdiction over all the region north of Missouri and lying between the Mississippi river and the Missouri river, and he appointed the Very Rev. Mathias Loras, then Vicar General of Mobile, Alabama, as the Right Rev. Bishop. He was consecrated in the Cathedral of Mobile on December 10, 1837, by the Rt. Rev. Michael Portier of Mobile, assisted by Rt. Rev. Anthony Blane, of New Orleans; and then made a visit to France and to the Pope at Rome. In 1838, Bishop Loras appointed Father Mazzuchelli as his Viear General and Administrator of Dubuque, which gave him the title of Very Rev. Samuel Mazzuchelli, V. G. O. P.

Rt. Rev. Bishop Mathias Loras, journeying on steamboat from St. Louis, arrived at Dubuque on Friday, April 19, 1839, and was installed in St. Raphael's Cathedral on Sunday, April 21st; and on the following Sunday, April 28, 1839, held public services in St. Michael's Church, Galena, Illinois, over which region he had been appointed as Vicar General of St. Louis.

Rt. Rev. Bishop Mathias Loras was a polished scholar and gifted orator, with a keen mind and mature judgment. His character was one of great gentleness and unflinching devotedness to his high vocation. He was well schooled in missionary life. Students today rank him as a saintly bishop and a great statesman.

On his arrival he found in a salubrious climate, a vast territory of unbroken prairies, which showed marvelous fertility of soil, teeming with grasses, flowers and game; dotted with beautiful groves; abundantly supplied with good water in springs, brooks and rivers. This territory was populated by about thirty thousand Indians, in addition to perhaps forty- 
three thousand white inhabitants, of whom nearly three thousand were Catholies. His only churches were St. Raphael's Dubuque; St. Anthony's, Davenport; St. James', Lee County, and the Jesuit Indian mission at Council Bluffs; there was not a house nor a school in the territory; and he was met by his only priest, Father Mazzuchelli. To the new diocese he presented the companions whom he brought from France, namely; the Rev. J. Anthony M. Pelamourgues, Rev. Joseph Cretin, and the seminarians Remigius Petiot, Augustin Ravoux, Lucien Galtier and James Causse. He at once entered upon his famous career. A brick residence was built at Dubuque under the direction and supervision of Father Mazzuchelli, to give quarters for bishop, priests and a seminary. Sehools and congregations were organized at various points. On May 23, 1839, he held episcopal visitation in Davenport, blessed the church, promised them a priest, and sent Rev. J. A. M. Pelamourgues in September of the same year, who opened a school at once, and who attended the entire region, which until 1846 often included Rock Island, Muscatine, Burlington and Iowa City. His memory is held in benediction by all the early settlers regardless of creed.

In July, 1839, the Bishop made his visitation to St. Peters, Minnesota, accompanied by Father Pelamourgues, and he made provision for that portion of the vineyard, and also for Prairie du Chien. He induced a young Indian to come back with him, to teach his young priests the Sioux language.

Rev. R. Petoit was ordained in the autumn of 1839 , and assigned to Galena, remaining on duty for many years in northwest Illinois and southwest Wiseonsin.

The Holy Order of Priesthood was administered for the first time in the great Northwest by Bishop Loras in his cathedral at Dubuque on January 5, 1840, when he ordained the Reverends Augustin Ravoux, Lueien Galtier and James Causse. Father Ravoux was sent to Prairie du Chien; Father Galtier to St. Peter's, Minnesota, and soon was built the first church in honor of St. Paul, which gave the name for the present city of that name. In 1844, Father Galtier was sent to Keokuk, and built the first church there. Later he was 
placed in charge of Prairie du Chien. In 1841, Father Ravoux took up his quarters in St. Peter's and became the great pioneer and Indian missionary of Minnesota.

The Bishop appointed Father Cretin specially in charge of the Winnebago Indians, and Father Pelamourgues of the Sac and Fox Indians. Father Cretin also was appointed Vicar General and given special direction for opening of schools, a seminary, and academies; in addition to which he joined with the Bishop in performing priestly functions on the missions wherever called, to preach, say mass, hear confessions, answer sick calls, teach the catechism.

In 1840, the Bishop endeavored to obtain Sisters for his schools. Being unsuceessful at this time, he in 1843, prevailed upon the Sisters of Charity of the Blessed Virgin Mary to remove their Motherhouse from Philadelphia to Dubuque. They arrived the same year under the guidance of Mother Frances Clarke, and immediately established schools in their new home.

The Very Rev. Terence Donaghoe was received as their director in 1843, and appointed as Vicar General of the diocese. He likewise aided in missionary work in Dubuque, Holy Cross, Bellevue and Maquoketa.

Father Mazzuchelli was assigned to attendance principally at Galena, Burlington, Iowa City and Muscatine; building St. Paul's chureh at Burlington in 1839; St. Mary's church at Iowa City in 1841 and Old Man's Creek the same year, and celebrating divine services at Fort Madison in 1839. He was constantly on duty until 1843 , when he made a visit to his old home in Milan, Italy, and upon his return remained in Wisconsin. Whilst in Italy he wrote an interesting account of his missionary labors which was printed in the Italian language.*

In 1840 and 1843 the Bishop attended the church council at Baltimore, Maryland.

In 1842, the Bishop organized the congregation of Holy Cross near Dubuque, and St. Andrew's church at Bellevue. He had two churches joined at Prairie du Chien and floated

* Memorie Istoriche ed Edificanti D'un Missionario Apostolico del Ordine del Predicatori. Milano. 1844." 
down the river in the shape of a raft, ordering one to be erected as St. Andrew's church at Bellevue, the other as St. Mathias' church at Muscatine. Furthermore, congregations were organized at New Vienna, Guttenburg, Fort Atkinson, Garnavillo, near Iowa City, St. Vineent's on English river, Ottumwa and Mt. Pleasant. He made many bishop's visitations from the years 1842 to 1846 .

From 1843 until 1846, Father Cretin made special efforts for the Winnebago Indians, and for their benefit resided part of the time in the Winnebago Mission (near Fort Atkinson), Iowa, and Prairie du Chien,

In 1841, Rev. J. C. Perrodin arrived and was appointed pastor of the Maquoketa church, Jackson County, and also attended Bellevue and other stations.

In 1840, Rev. John G. Alleman eame here from the Dominieans in Ohio and built a brick church 16 by 18 feet in dimensions, in Fort Madison, the St. Joseph's congregation, where he built a larger church in 1844 . He built a frame church, about 20 by 40 feet in size in West Point in honor of St. Philip, and also attended the churches at St. Paul, Primrose, Farmington and Keokuk. From then until 1848, he spent most of his time in Lee County, Iowa, but was often absent in the performance of missionary duties in Burlington, Dubuque and wherever he heard of the arrival of German immigrants. In 1846 he organized a congregation in the St. Vincent settlement (two miles west of the present Riverside, Washington County), aided by the Schnoebalen and Edelstein families; built a log church and laid out a town site which was named Strassburg.

In 1843, Rev. John Healey was appointed pastor of Burlington, and later resided with the Bishop at Dubuque, and then was appointed pastor of Bellevue.

In 1843, Rev. Anthony Godfert was appointed pastor of Iowa City, and from there also made visits to Museatine, Burlington, Old Man's Creek and Washington County.

Rev. James Causse was on duty part of the time at Dubuque, but later on resided chiefly at Potosi, Wisconsin. 
All these clergymen were assiduous and diligent, and went about everywhere in humility and apostolical zeal, whilst their conduct and holy character commanded the confidence and admiration of all classes.

Thus 1846 found us with an academy for boys at Dubuque, conducted by priests of the cathedral. Mother Frances Clarke had in her community thirteen sisters and seven novices, an academy with seventy young ladies, and several schools.

The Indian mission at Council Bluffs was organized by the Jesuit missionaries from St. Louis, under the jurisdiction of Bishop Loras. They arrived at Council Bluffs on the morning of May 30,1838, and were received with great joy by the Indian ehiefs and braves, mostly Pottawattamies. The company consisted of the Jesuit Fathers Rev. Felix Verreydt, Rev. J. De'Smet, and Brother Mazelli. These took possession of the vacated soldiers' barracks, at the site of the present Pierce school, near the church of St. Peter and Paul. They conducted regular services, built several more log houses, had an Indian school with generally an attendance of about thirty children, baptized about one hundred in the first year, in spite of many obstacles; and on Our Lady Day, August 15, 1838, they celebrated high mass, at which the entire Latin singing was chanted by the Indians. Father Christian Hoecken, Jesuit, also aided in this mission. However, with the dispersion of the Indians the mission waned, and by the year 1843 was almost abandoned; although the chapel with its cross, little tower and chapel bell remained in place for many years, and was seen there by Rev. Father William Emonds when he was resident pastor of Council Bluffs as late as 1855. Hard by this chapel was a cemetery, and many years later, when the streets were graded, the historic traces appeared in the finding of Indian shells, of rosary beads and medals.

The activity of the Bishop and his priests eontinued; but our study comes to a close with the Territorial days of Iowa in 1846, at which time we find the Bishop with the same vast territory, in good bodily and mental vigor, aided by Rev. John G. Alleman at Fort Madison; Very Rev. Joseph Cretin, 
at Dubuque; Very Rev. Terence Donaghoe, at Dubuque; Rev. Anthony Godfert, at Iowa City; Rev. J. A. M. Pelamourgues, at Davenport; Rev, J. C. Perrodin, at Maquoketa; Rev. H. Herrog, at Burlington; with the Indians mostly gone from Iowa, but large numbers of Sioux, Chippewa, Mandans and Winnebago in Minnesota, under-the eare of Rev. Father A. Ravoux near Fort Snelling, and Rev. George A. Bellecourt, Pembina; with several academies and schools under the guidanee of twenty Sisters of Charity, several priests, and some lay teachers; thirteen ehurches, nine stations, and a Catholic population of nearly seven thousand.

In the directories for Dubuque, we sometimes come across the announcement as occasion required, "Sermons preached in English, German, French or Sioux" language.

In 1844, the dioceses of Chicago and Milwaukee were created, and some of the Dubuque priests remained there, as follows: Very Rev. Samuel Mazzuchelli, Rev. Lucien Galtier, and Rev. James Causse in Wiseonsin; Rev. Remigius Petiot in Illinois.

\footnotetext{
*Authorities used for this paper in addition to personal acquaintance and interviews with many prelates, priests and pioneer settlers are:

Annals of the Faith, Annuals, Dublin edition, for the years 1838-1863 ;

Catholic Directories, for the years 1833 and $\mathrm{ff}$.;

Baptismal Registers, Dubuque, Council Bluffs, etc. ;

Memorie Istoriche (Father Mazzuchelli) Milan, Italy, 1844;

Letters and Reports, seen by me, and extracts taken through courtesy of Very Rev. Father Vander Sanden, in St. Louis, Missouri, in 1886, written to Bishop Joseph Rosati by Rev. John McMahon, from Galena; Rev. Charles P. Fitz-Maurice, from Galena; Rev. P. P. Lefevre, from St. Paul's, Ralls County, Missouri; Rev. August Brickwedde, Quincy, Illinois; Rev. Samuel Mazzuchelli, from Dubuque, Iowa, etc.-J. F. K.
} 
Copyright of Annals of Iowa is the property of State of Iowa, by \& through the State Historical Society of Iowa and its content may not be copied or emailed to multiple sites or posted to a listserv without the copyright holder's express written permission. However, users may print, download, or email articles for individual use. 